\author{
Volume and Issues Obtainable at Center for Sustainability Research and Consultancy \\ Journal of Accounting and Finance in Emerging Economies \\ ISSN: 2519-0318ISSN (E) 2518-8488 \\ Volume 4: Issue 2 December 2018 \\ Journal homepage: publishing.globalcsrc.org/jafee
}

\title{
The Relative Efficiency of Commercial Banks in Pakistan with Respect to Size and Ownership Structure During and After Global Financial Crisis
}

\author{
${ }^{1}$ Allah Bakhsh khan, ${ }^{2}$ Syed Zulfiqar Ali Shah, ${ }^{3}$ Muhammad Abbas, ${ }^{4}$ Qaiser Maqbool khan \\ ${ }^{1}$ Asst Professor (Commerce) Bahauddin Zakariya University, Multan, and PhD Scholar at International \\ Islamic University, Islamabad. Pakistan. Email: abkhan@bzu.edu.pk \\ ${ }^{2}$ Associate Professor, Faculty of Management Sciences, International Islamic University, Islamabad. \\ Pakistan. \\ ${ }^{3}$ Assistant Professor, Air University, Multan Campus. Email: mam@aumc.edu.pk \\ ${ }^{4}$ PhD Scholar at Department of Commerce, Bahauddin Zakariya University, Multan. Pakistan. \\ Email:qmk707@gmail.com
}

\begin{tabular}{l}
\hline ARTICLE DETAILS \\
\hline History \\
Revised format: $\quad$ Nov 2018 \\
Available Online: Dec 2018
\end{tabular}

\section{Keywords}

Efficiency, Banks,

Financial Intermediation,

Moral Hazard, Data

JEL Classification:

D61,E58,E44,Y10

\section{ABSTRACT}

Purpose: This study has been carried out to find out the relative efficiency of the commercial banks in Pakistan over a five- year period from 2006 to year 2010 using Frontier Approach of efficiency. The commercial banks included in this research paper are public sector banks, privatized banks, domestic private banks, and foreign banks. In addition to overall efficiency comparison of the commercial banks, this study has also tested the effect of size and ownership structure of the commercial banks in Pakistan on their efficiency.

Data/Design/Methodology/Approach: Out of 44 banks, 21 commercial banks have been chosen, which, in terms of deposits, account for about 94 percent of total deposits of the banking sector (Rs.5,124,308 million) as on December, 2010. Secondary data of the banking firms have been gathered from their audited financial statements. Intermediation approach has been used by employing Data Envelopment Analysis. The relative efficiency of the commercial banks has been investigated in context of intermediation approach which transforms labor and capital into advances/loans and investments.

Findings: Over all a very few commercial banks have achieved $100 \%$ efficiency. It is, however found that privatized and domestic private banks have shown better efficiency in terms of financial intermediation as compared to public sector and foreign banks. The size of the banks has a very slight effect on the relative efficiency of the banks. The global financial crisis has affected the efficiency of some of the commercial banks but for a small period of time.

Originality: This paper is an attempt to find out the relative efficiency of the commercial banks during the mentioned period which lies during the Global Financial Crisis. Its findings would be of great value for every stratum of society including bankers, business community, academicians, and government and of course, the investors.

(C) 2018 The authors, under a Creative Commons AttributionNonCommercial 4.0

Corresponding author's email address: abkhan@bzu.edu.pk 
Recommended citation: ${ }^{1}$ Khan, A.B. ${ }^{2}$ Shah, S.Z.A. ${ }^{3}$ Abbas, M. ${ }^{4}$ Khan, Q. M. (2018). The Relative Efficiency of Commercial Banks in Pakistan with Respect to Size and Ownership Structure during and after Global Financial Crisis. Journal of Accounting and Finance in Emerging Economies, 4(2) 123-132

DOI: $10.26710 /$ jafee.v4i2.524

\section{Introduction}

The financing activities of firms are one of the key financial decisions. Firms have to issue/create debt and equity instruments for financing their operations and investments. Broadly, there are two main sources of finances available: financial institutions and capital markets. In some countries like USA and UK, capital markets have been predominantly used where as in countries such as Germany, Italy, Japan etc. the banks have been the major source of finances. The commercial banks are also the major source of finances in developing countries like Pakistan as capital markets are not very much developed over there.

The banks have been comparatively more efficient especially in terms of cost and information as compared to the capital markets. The advantage of capital markets being the provider of large size finances has also been subsided by the introduction of syndicated loans. An early description of the informational advantages of financial intermediation, obtaining funding through an intermediary is found in the 1977 article by Leland and Pyle, which focused on the moral hazard problem between borrowers and lenders. The financial institutions may have more accurate information about the borrowers and their projects due to their professional expertise and that are relatively low cost than capital markets. The shareholders of firms realize positive returns following the announcement that their firm has obtained a loan from a commercial bank (James, 1987; Magginson, Poulsen, and Sinkey, 1995).

Banking sector's contribution to the national economy is substantial and financial intermediation provided by them in screening and monitoring borrowers can solve moral hazard and adverse selection issues faced in the information provided by borrowers and lenders.(Hughes, 2008). Financial sector plays a crucial role in development and progress of a country's economy.

The banking sector in Pakistan provided domestic credit equivalent to 46.28 percent of Gross Domestic Product (GDP) in the year 2010 which was 48.44 percent in the year 2009. The same was 53.21 percent in 2008. Pakistan inherited not very progressive financial sector at the time of independence. In Pakistan, financial sector comprises of regulator (SBP), commercial banks, investment intermediaries, development finance institutions, saving banks and stock markets. The banking history of Pakistan is as old as Pakistan itself. Due to the high regulations and more intervention of government authorities, the performance of banking sector was not up to the satisfactory level in the 70s and early 80s when most of the financial institutions were in public sector. Hence, the banking efficiency remained very low. According to Fitch ratings, an international credit rating agency (at New York and London), the Pakistani banking system has gradually evolved from a weak state-owned system to slightly healthier and active private sector driven system. Pakistani banking sector has not been affected by the external shocks especially the financial crisis 2007-08, as it influenced the banks in Europe and USA.

Financial reforms were introduced in different phases since 1991 and as a result, Pakistan banking sector moved towards liberalization and financial sector deregulation. Since then the banking sector has made tremendous growth but still a lot of competitive deficiencies prevail in the sector. The number of commercial banks has been established in the private sector, some major public sector banks have been privatized (ABL, HBL, MCB, UBL) and a number of commercial banks have merged into other banks (The Royal Bank of Scotland, Pakistan into Faisal bank, Atlas bank into Arif Habib bank renamed as Summit bank). The total number of commercial banks including public sector banks, domestic private banks, privatized banks and foreign banks are 44 (SBP website 2011)

The commercial banks in Pakistan now are working within a competitive environment and thus the management of every bank is striving hard to improve the efficiency of their bank so as to become more 
efficient or at least to maintain their previous rating among the peers. The State Bank of Pakistan, since its autonomy in 1990s has provided all the banks with a very innovative policies and a level playing field for healthy rather tough competition. The regulator, the government departments, public from all walks of life and even employees and management of the banks remain concerned with the performance of the banks. Intuition and a vast amount of empirical evidence have proved that a best bank in one year may not maintain its superiority in the following or next years. Being a very sensitive sector, a good performing bank may fall in troubles and even may go into bankruptcy as has happened around the globe during 2007-08 such as Lehmon Brothers (one of the America's largest financial services entity) which filed for bankruptcy on September, 2008.

In Pakistan, a few studies have been carried out on the efficiency measurement of commercial banks but most of them are conducted before the global financial crisis 2007-08. It is therefore imperative to investigate the efficiency of the banks during and after this crucial period. This study has therefore been carried out to look for the relative efficiency of the commercial banks over a five- year period from 2006 to year 2010 by employing Data Envelopment Analysis and SPSS. The commercial banks included in this research paper are i) public sector banks, ii) privatized banks, iii) domestic private banks, and iv) foreign banks. This study has excluded domestic saving banks and specialized financial institutions because of very different nature of their operations. It has also excluded the newly emerging Islamic banks due to their different parameters of efficiency measurement.

This study will be of great value for the government, its various departments, the regulator, general public, business community, employees and management of the banks as well as investors, both foreign and local. It will be a good enough addition in the practical and academic knowledge. The specific objectives of the study are:

To measure the overall relative efficiency of the commercial banks in Pakistan for each year in the period 2006 to 2010

To measure the relative efficiency of the commercial banks in Pakistan over the same period with respect to their ownership structure (private, public, foreign, privatized).

To evaluate the relative efficiency of the commercial banks in Pakistan with respect to the size of the banks.

\section{Literature Review}

There have been several efforts to investigate the efficiency of the commercial banks in the world over and in Pakistan as well. Given below is a brief description of the researches made in different countries including Pakistan.

Saha and Ravisankar (2000) evaluated technical efficiency of 25 Indian commercial banks by using the DEA and computed the efficiency of a bank in transforming inputs into outputs in relation to its peer group. Their results depicted that the public sector banks have made improvements over the years.

Zajc (2006) in his comparative study of bank efficiency in Central and Eastern Europe criticized the studies of the performance of banks which often focus on the presentation of financial ratios and the analysis of scale and scope economies. He preferred for using non-parametric efficiency estimation techniques such as DEA and the free disposable hull (FDH), and three major parametric techniques: the stochastic frontier analysis (SFA), the distribution free approach (DFA) and the thick frontier approach (TFA). His study concluded that foreign banks are less cost efficient than domestic banks.

Supachet Chancern (2008) examined the relative efficiency of commercial banks in Thailand for a period of 4 years by utilizing a non-parametric analytical technique: Data envelop analysis. In this study, DEA 
model has been used under two different approaches in evaluating the relative efficiency of commercial banks in Thailand: Operating approach and Intermediation approach. The operating approach evaluated the efficiency from the cost/revenues management and showed average efficiency of the Thai commercial banks over 90 percent in every year where as by intermediation approach though high but volatile with the average efficiencies about 86 percent in 2003, 72\% in 2004, again 86 percent in 2005 and 72 percent in 2006.

Hughes (2008) gives an overview of two general empirical approaches to measuring bank performance: nonstructural and structural. The nonstructural approach compares performance among banks and considers the relationship of performance to investment strategies and other factors such as characteristics of governance. The structural approach is choice-theoretic and, as such, relies on a theoretical model of the banking firm and a concept of optimization

Some recent research work made with respect to efficiency of Pakistani commercial banks is narrated below:

Akhter (2002) made studies on concept of X-efficiency of commercial banks for the year 1998 taking cross sectional data and by using DEA approach. He investigated technical efficiency and allocative efficiency of 40 banks. Private banks in Pakistan emerged as efficient on both fronts i.e. technical efficiency and allocative efficiency, compared to their counterparts, the public and foreign banks.

Ahmad (2008) in his doctoral thesis on the subject used DEA to capture multiple outputs. He used input oriented of DEA under constant returns to scale (CRS) and variable returns to scale (VRS). He opted for intermediation approach to define the inputs and outputs of the commercial banks. Besides, nonparametric approach, he used Tobit Model to develop the relationship between efficiency scores and factor efficiency. He concluded that commercial banks can improve the efficiency by increasing profits, assets, mark-up interest earnings and non-mark up interest earnings, and decreasing liabilities, mark-up interest expenditures and non-mark-up interest expenditures among the bank specific variables.

Akmal and Saleem(2008) analyzed the technical efficiency of thirty Pakistani Banks over a period 19962005 by using DEA approach. They concluded that overall banks in Pakistan improved their performance especially after 2000. It was found that there was about 12 percent technical inefficiency under CRS and 9 percent under VRS assumptions. It found 4 percent scale inefficiency in the banking sector.

Rehman and Raoof (2010) made a comparison between public, private and foreign banks efficiencies. They analyzed 40 commercial banks for the period of ten year (1998-2007) and employed data envelopment analysis (DEA) to compute their efficiencies. Their study show results show that foreign and private sector banks were well ahead of pubic sector in term of technical efficiency in the initial years but in the next years public sector banks were the best. The reason stated by them was massive privatization which resulted into the inefficiency of private sector in comparative terms

Janjua and Malik (2011) analyzed cost inefficiency of 15 Pakistani commercial banks during 1990 to 2006. The cost structure of banks has been defined under intermediation approach. For results estimation, free distribution approach has been used. The study mainly finds that cost inefficiency varies across the banking industry. If ranked, a foreign private bank is found as the best practice bank or a cost frontier. As regards the contributory factors of cost inefficiency, these are non-performing loans which contributed largely to the cost inefficiency of banks, followed by financial prices, advances, and investment. In terms of cost efficiency, foreign private bank was found to be the best practice bank and estimated as a cost frontier. The relative efficiencies of other banks worked out in the range of 97.13 percent (foreign bank) to 59.23 percent (a privatized bank).

It is concluded from the above studies that both parametric such as SFA, DFA or TFA and non-parametric 
approach i.e DEA can be used to evaluate the relative efficiency of the commercial banks in terms of technical, allocative, scale and operating context.. For working out the technical efficiency of the commercial banks, DEA can be comfortably used.

\section{Data Collection and Research Methodology}

The data has been taken from the annual financial reports of the respective banks and various statistics published by State Bank of Pakistan. The study has collected data on 21 commercial banks with different ownership structure and different sizes, out of total 44 scheduled banks as per website of the state Bank of Pakistan 2011 which according to State Bank of Pakistan monthly statistics, account for about 94 percent in term of total deposits of the banking sector in Pakistan (December 2010). Except three foreign banks, all other banks (18) are listed with the Karachi Stock Exchange. The total listed number of banks is 26. The cross sectional data for each commercial bank, as an entity, has been taken for each calendar year from 2006 to 2010 .

\subsection{Efficiency Measurement approach and Variables}

The study has taken three inputs: deposits, total expenses and labour, and two outputs: total advances and investments. Intermediation approach has been used for measuring the relative efficiency of the commercial banks which uses labour and capital to convert deposits into advances, loans and investments. The input and out put variables for the chosen approach are given below:

Input $1=$ no of employees (staff strength excluding outsourced)

Input $2=$ total expenses (in thousand Rupees)

Input $3=$ total deposits(in thousand Rupees)

Output $1=$ Total advances and loans (in thousand Rupees)

Output $2=$ investments (in thousand Rupees)

This study has initially taken the following banks for the year 2006 to 2008.

\section{Public sector Banks:}

\section{National Bank of Pakistan 2. The Bank of Khyber 3. The bank of Punjab}

\section{Privatized Banks:}

1.Habib Bank Limited

3. United Bank Limited

Private Domestic Banks:

1. NIB bank

3. Summit Bank (formerly Arif Habib Bank limited)

Alfalah limited

Chartered Bank

Foreign Banks:

1. The Bank of Oman
6 .Bank Al Habib Limited

9.Habib Metropolitan Bank

2. The Faisal Bank Limited
2.Allied Bank Limited

4. MCB Bank Limited

2. Atlas Bank limited
5.Bank

8.Standard

In the year 2009, the data of 20 banks have been taken due to non-availability of annual report of the bank of Punjab for the year where as number of banks taken in 2010 reduced to 19 as Atlas bank has been merged into Summit Bank(formerly Arif Habib bank).

\subsection{Research Methodology:}

As mentioned above, the study has focused on the intermediation approach for the investigation into relative efficiency of the commercial banks. For analysis purpose, Data envelopment analysis is being employed. The study is investigating the efficiency from three perspectives: i) overall relative efficiency of each of the commercial banks in Pakistan during the five year period 2006-2010. ii). Relative efficiency of the banks with respect to Size, where total assets have been taken as the proxy for size categorization. iii) the relative efficiency of the banks with respect to their ownership structure i.e.,Public sector banks, Privatized banks, Domestic private banks and Foreign banks.

As per ownership structure, these four categories have been analyzed and with respect to size of total 
assets, all the banks have been classified into three different classes: large, medium and small.

In data envelopment analysis, Score 1 is taken as $100 \%$ efficiency and the banks with score 1 will be declared as the best bank(s). The banks with score less than 1 will be termed as inefficient. A bank obtaining a score closer to 1 will be near to efficiency and vice versa. An efficiency frontier is developed by different combinations of the best banks, which in turn becomes the yardstick for measuring the efficiency or otherwise of the other banks. The farther a bank is from efficient frontier, the more efforts it will need to achieve efficiency.

\subsubsection{Data Envelopment Analysis:}

There are two analytical techniques being used to measure the relative efficiency of financial institutions: parametric and non-Parametric. The parametric approaches include the SFA (stochastic frontier approach), the TFA (thick frontier approach) and the DFA ( distribution free approach). The nonparametric approaches include the DEA (data envelopment approach) and the FDH (free disposal hull). Most of the studies on efficiency of commercial banks around the world and in Pakistan have used the DEA (Akhter, 2002; Ahmad, 2008; Akmal and Saleem, 2008). This study is also using DEA to measure the relative efficiency of the commercial banks in context of their intermediation.

The DEA utilizes cross sectional data of decision making units (DMUs) with multiple inputs and multiple outputs. It is imperative to mention here that the inputs and outputs of DMUs being compared should be same to employ DEA. In this non-parametric analytical technique, first of all a benchmark is worked out and then inefficiencies of other DMUs are found with respect to the benchmark. A study by Farrel (1957) is quoted where DEA was first used to analyze the technical efficiency of production taking one input and one output. However, Charnes, Cooper and Rhodes (1978) developed this single input -output model into multiple inputs and multiple outputs situations latterly referred to as CCR model. The DEA was further extended by Banker, Charnes and Cooper in 1984. The difference between the last two developments is that the former study assumed a constant return to scale whereas the later, also added the assumption of variable return to scale.

DEA can be thought of like a regression analysis but with the difference that DEA does not require a functional relationship between inputs and outputs as required in case of regression analysis. Moreover, regression analysis compares different DMUs with the average value of all DMUs where as DEA first determines a best DMU as benchmark and then compares other DMUs (entities) with the benchmark..

\subsubsection{Model Specification}

This study uses CCR model in order to measure the relative efficiency of each commercial bank in Pakistan. The CCR model considered in this study is an output-oriented model which means to produce the highest level of output with a given amount of input. His model defines the efficiency as under:

Efficiency $=$ weighted sum of outputs/Weighted sum of inputs

The weights of the ratio are determined by the ratio by the restriction that the similar ratios for every DMU.

$\operatorname{Max} \mathrm{h}_{\mathrm{o}}(\mathrm{u}, \mathrm{v})=\left(\sum_{r=1}^{s} v_{\mathrm{r}} \mathrm{y}_{\mathrm{r} 0}\right) /\left(\sum_{i=1}^{m} u_{\mathrm{i}} \mathrm{xi}_{0}\right)$

subject to

$\left[\sum_{r=1}^{S} v_{\mathrm{r}} \mathrm{y}_{\mathrm{rj}}\right] /\left(\sum_{i=1}^{m} u_{\mathrm{i}} \mathrm{x}_{\mathrm{ij}}\right) \leq 1 \quad \mathrm{j}=1,2, \mathrm{n}$

$\mathrm{u}_{\mathrm{i} \geq 0 ;} \mathrm{i}=1,2,, \mathrm{~m}$

$\mathrm{v}_{\mathrm{r}} \geq 0 ; \mathrm{r}=1,2, \mathrm{,} \mathrm{s}$

Where

$\mathrm{x}_{\mathrm{ij}}=$ the amount of input I utilized by the $\mathrm{jth}$ DMU 
$y_{\mathrm{rj}}=$ the amount of out put $\mathrm{r}$ produced by the jth DMU

$\mathrm{u}_{\mathrm{i}}=$ weight given to input $\mathrm{i}$

$\mathrm{v}_{\mathrm{r}}=$ weight given to out put $\mathrm{r}$.

\section{Results:}

\subsection{Overall Efficiency Analysis of Commercial Banks in Pakistan.}

The summery results of the selected banks are given in table1.The efficiency of the banks varies from 100 $\%$ to $47 \%$. The average efficiency of Pakistani commercial banks ranges from $80 \%$ to $92 \%$ in the study period which is quite reasonable from the perspective of other developing countries. However, out of 21 , seven banks were found efficient in the year 2006 while two-third of the selected banks remained inefficient from $1 \%$ to $41 \%$. The bank of Oman witnessed the lowest efficiency.

In 2007, the number of efficient banks in Pakistan reduced to five out of whom four were the same as in 2006 i.e MCB bank, Summit bank, Habib Metropolitan Bank,and Faisal bank. The average efficiency also dropped from $89 \%$ to $85.9 \%$.

In the year 2008, the number of efficient banks reduced to four, three of which were again the same i.e MCB bank, Habib Metropolitan Bank, and Faisal bank. The average efficiency declined further to about 80 percent.

In the year 2009, the number of efficient banks increased to six out of which two banks namely Habib Metropolitan Bank, and faisal bank retained their efficient position where as MCB bank remained short of efficient bank by 65 . The average efficiency of the banks increased to $89 \%$.

In the year 2010, the number of efficient banks further increased to eight in which Habib Metropolitan Bank still remained efficient for the fifth consecutive year. The MCB bank once again achieved 100\% efficiency after some inefficiencies $(6 \%)$ in the previous year. ABL and UBL who achieved $100 \%$ efficiency in 2009, also maintained their efficient position in the year 2010. The average efficiency of the banks during the year experienced another improvement and achieved an efficiency of $92 \%$.

The following banks have never been able to achieve the $100 \%$ efficiency position through out the study period of five years.

1. National Bank of Pakistan 2.Habib Bank Limited 3.Askari Commercial Bank 4. Soneri Bank 5. Bank of Oman 6. Bank of Khyber 7. Bank of Punjab (3years)

The Habib Metropolitan bank remained an efficient bank over the entire study period where as MCB bank and Faisal bank remained efficient for the four years while slightly short of the target in one year.

Table 1: Relative efficiency of commercial banks in Pakistan

\begin{tabular}{|l|l|l|l|l|l|}
\hline Name of bank & 2006 & 2007 & 2008 & 2009 & 2010 \\
\hline NBP & 0.780515 & 0.893586 & 0.912862 & 0.888442 & 0.854202 \\
\hline HBL & 0.906235 & 0.895104 & 0.715292 & 0.911195 & 0.947178 \\
\hline ABL & 0.842925 & 0.797859 & 0.797359 & 1 & 1 \\
\hline ACB & 0.841442 & 0.824692 & 0.681627 & 0.852349 & 0.855008 \\
\hline UBL & 0.852922 & 0.934731 & 0.794115 & 1 & 1 \\
\hline Bank Alfalah & 0.680013 & 1 & 0.67342 & 0.771989 & 1 \\
\hline MCB & 1 & 1 & 1 & 0.943517 & 1 \\
\hline NIB & 1 & 0.864359 & 0.846418 & 1 & 1 \\
\hline Summit(Arif Habib) & 1 & 1 & 0.881917 & 0.793155 & 0.840803 \\
\hline Habib Metro Bank & 1 & 1 & 1 & 1 & 1 \\
\hline Standard Charterd bank & 0.997036 & 0.788451 & 0.703041 & 0.885639 & 0.950482 \\
\hline Soneri Bank & 0.780194 & 0.781527 & 0.685483 & 0.864541 & 0.910242 \\
\hline Bank of Oman & 0.591303 & 0.560227 & 0.471352 & 0.661276 & 0.751886 \\
\hline
\end{tabular}




\begin{tabular}{|l|l|l|l|l|l|}
\hline Bank Al Habib & 0.889061 & 0.811119 & 1 & 0.938731 & 1 \\
\hline HSBC Bank & 0.856461 & 0.905833 & 0.687317 & 1 & 0.701583 \\
\hline Atlas Bank & 1 & 0.709624 & 0.977813 & 0.935419 & - \\
\hline Bank of Khyber & 0.938222 & 0.746919 & 0.883301 & 0.88584 & 0.886361 \\
\hline CITI Bank & 0.893164 & 0.83719 & 0.672485 & 0.84391 & 1 \\
\hline JS Bank & 1 & 0.782849 & 0.807539 & 0.661063 & 0.803889 \\
\hline Faisal Bank & 1 & 1 & 1 & 1 & 0.967584 \\
\hline Bank of Punjab & 0.855718 & 0.90009 & 0.71241 & - & - \\
\hline Average Score & 0.890724 & 0.85877 & 0.804941 & 0.891853 & 0.919433 \\
\hline
\end{tabular}

\section{2:Analysis of commercial banks with respect to ownership structure}

The commercial banks in Pakistan fall into four categories with respect to ownership structure. Category 1 consists of three public sector banks which include the National bank of Pakistan, the Bank of Punjab and the Bank of Khyber. The second category includes the four privatized banks namely Habib bank limited, Allied Bank limited, MCB bank limited and United Bank limited. These banks have been in the public sector since nationalization of banks in 1974 and have been privatized in the last decade or so. The third category consists of newly established commercial banks set up in the private sector after financial liberalization in the late 1990s and afterward. These are Askari commercial bank, bank Alfalah, NIB bank, Summit (Arif Habib) bank, Habib Metropolitan bank, Soneri bank, bank al Habib, Atlas and JS Bank. The foreign banks have been placed in the fourth and last category. They are Standard Chartered bank, The Bank of Oman, HSBC bank, Faisal bank and CITI bank.

An overall analysis of the selected commercial banks in terms of ownership structure has been made by using DEA and then SPSS for the period under study. The results are given in table 2.

The mean value column of the table depicts that on average none of the class was found as efficient banking category .However, privatized banks and the domestic private banks showed better efficiency than public sector banks and foreign banks. The last category is the most inefficient in their intermediation role. This may be due to the lowest efficiency of the Bank of Oman and then Standard Chartered bank. These two foreign banks remained highly efficient during the years 2007 \& 2008 .

Table 2 Efficiency of commercial banks with respect to ownership structure (2006-2010)

\begin{tabular}{|l|l|l|l|l|}
\hline GRP1 & Mean & Std. Deviation & Minimum & Maximum \\
\hline $\begin{array}{l}\text { Public sector } \\
\text { banks } \\
\begin{array}{l}\text { Privatized } \\
\text { banks } \\
\text { Domestic } \\
\text { private banks }\end{array}\end{array}$ & .8568 & .06780 & .71 & .94 \\
$\begin{array}{l}\text { Foreign Banks } \\
\text { Total }\end{array}$ & .8287 & .08931 & .72 & 1.00 \\
\hline
\end{tabular}

\section{3: Analysis of Commercial banks' Efficiency with respect to size classification.}

As a last and final analysis, the study has investigated the relative efficiency of the commercial banks by classifying the sample banks into three broad classes on the basis of total assets (2010): large, medium and small. Keeping the range of total assets of the selected banks, the study has made three ranges of classification. Banks having total assets of Rs.0.500 billion and above, have been placed in large category; the medium range contains the banks with total assets from Rs.0.100 billion to Rs0.499 billion and third category designated as small consists of the commercial banks with total assets of less than Rs0.100 
billion.

According to this scheme of classification, the banks are placed as against the relevant category, as under:

\begin{tabular}{|l|l|}
\hline Category & Name of the banks \\
\hline Large & National Bank, Habib Bank, Allied Bank, United Bank ,MCB bank \\
\hline Medium & $\begin{array}{l}\text { Askari bank, Bank Alfalah, NIB bank, Habib Metropolitan Bank, } \\
\text { Standard Chartered, Soneri Bank, Bank al-Habib, Faisal Bank \& Bank of Punjab }\end{array}$ \\
\hline Small & Summit bank, Bank of Oman,,HSBC Bank, Bank of Khyber, Citi Bank and JS Bank \\
\hline
\end{tabular}

The relative efficiency analysis of the commercial banks according to size is given in table 3 .

When grouped into three categories, none of the class shows $100 \%$ efficiency. It is, however observed that large banks are comparatively more efficient than the medium and small group of banks. The result tends to state the size of the bank does matter in assessing relative efficiency of the commercial banks. However, this result can not be generalized due to average of efficient and inefficient banks in each class as witnessed in the analysis of banks individually and over the year.

Table 3 Efficiency Analysis of commercial banks with respect to size

\begin{tabular}{|l|l|l|l|l|}
\hline GRP2 & Mean & Std. Deviation & Minimum & Maximum \\
\hline Large banks & .9067 & .08487 & .72 & 1.00 \\
Medium & .8910 & .11215 & .67 & 1.00 \\
banks & & .14015 & .47 & 1.00 \\
Small banks & .8226 & .12097 & .47 & 1.00 \\
Total & .8721 & & \\
\hline
\end{tabular}

\section{Conclusion}

From the above analysis, it is found that the relative efficiency of the banks in Pakistan varies from $100 \%$ to $47 \%$ during the period 2006 to 2010 . The average efficiency of Pakistani commercial banks ranges from $80 \%$ to $92 \%$ which is quite reasonable from the perspective of other developing countries. A very few banks have been found almost efficient consistently. The privatized banks especially MCB bank has performed efficiently during the period where as Allied Bank and United Bank have become efficient in the last two years (2009 \& 2010). Over all, the Habib Metropolitan bank, a domestic private bank, has been found an efficient bank through out the period of analysis. The Faisal bank has also been an efficient bank during the year 2006 to 2009. However, its efficiency slightly decreased in the year 2010.

As far as relative efficiency of the commercial banks is concerned with respect to ownership structure, the privatized and the domestic banks have been more efficient than public sector banks as well as the foreign banks. Moreover, there seems to an effect of size on the efficiency of the banks but it is not that significant to be generalized. One important empirical finding of this study is that the commercial banks were affected by the global financial crises up to some extent as their average efficiency declined in the year 2007 and 2008.

This research has certain limitations such as all commercial banks have not been included in the study. Though the left over banks account for a very small proportion of total banking sector, it would have been preferable that all the banks might have included. Moreover, the determinants of efficiency may be found using second stage analysis. This study, however, has given a fair enough view of the banks' efficiency. 


\section{References}

Ahmad,T.(2008), "Efficiency Analysis of Commercial banks in Pakistan", Department of Development Economics, University of Agriculture, Faisalabad.

Akhter, M.H. (2002), “ X-Efficiency Analysis of Commercial Banks in Pakistan: A Preliminary investigation", Department of Commerce B. Z. University, Multan, Pakistan.

Akmal, M., and Saleem, M. (2008), "Technical efficiency of the Banking Sector in Pakistan.", SBP Research Bulletin, Vol.4, Nov.2008.

Chansarn, C.(2008), "The Relative Efficiency of Commercial Banks in Thailand: DEA Approach", International Research Journal of Finance and economics, issue 18, pp.53-68.

Hughes, J.P., and Mester,L.J.(2008), "Efficiency in Banking: Theory, Practice, and Evidence”, Federal Reserve Bank of Philadelphia and The Wharton School, University of Pennsylvania.

James , c.(1987), "Some Evidence on the Uniqueness of Bank Loans", Journal of Financial Economics vol.19, pp.217-236.

Janjua, M.A., and Malik, M.H.(2011), "The Cost efficiency Analysis of Commercial Banks in Pakistan: based on Free Distribution approach." Department of Economics, Karachi and State Bank of Pakistan ,Karachi

Leland, Hayne, and Pyle, D.(1977) "Information Asymmetries, Financial Structure, and Financial intermediation”, Journal of Finance, vol.32, pp.371-387

Rehman, R., and Raoof, A.(2010), “Efficiencies of Pakistani Banking Sector: A Comparative Study”, International Research Journal of Finance and Economics, Euro Journals Publishing, Inc.

Saha, A., and Ravisankar, T.S.(2000), "Rating of Indian commercial banks: A DEA approach", European Journal of Operational Research pp.187-203.

Zajc, P. (2006), “A comparative Study of Bank Efficiency in Central and Eastern Europe: The Role of Foreign Ownership", International Finance Review, vol.6,117-156. 